\title{
Primary Sources in the College Classroom: The Beck Archives at the University of Denver Libraries
}

\section{Jeanne Abrams}

Beck Archives of Rocky Mountain Jewish History, University of Denver's Libraries

\begin{abstract}
The University of Denver's Libraries' Special Collections, which include the Beck Archives of Rocky Mountain Jewish History, have made a concerted effort to encourage faculty to incorporate the use of primary sources into their undergraduate curricula. Teaching teams, consisting of special collections curators, reference and instruction librarians, and faculty members, used both digital and physical primary resources to engage students. These efforts led to the DU project's being named the recipient of the 2018 Primary Source Award for Teaching from the Center of Research Libraries. This article details the project and highlights the Beck Archives items, which were especially effective as teaching materials.
\end{abstract}

Keywords: primary sources; undergraduate curricula; teaching teams; Special Collections and faculty partnerships

\section{INTRODUCTION}

For the last several years, the Special Collections department in the university libraries at the University of Denver (DU), where the Beck Archives of Rocky Mountain Jewish History resides, has made a concerted effort to encourage faculty across the disciplines to incorporate the use of primary sources into their teaching curricula. Similar programs have emerged in other institutions and have become an especially strong focus within the archive community (Yaco, Brown, and Konrad 2016; Garcia 2017; Norman and Oliver 2014).

As an early adopter, the DU Libraries developed a teaching model for first-year seminars and upper division courses that stresses the value of primary sources in research. Between 2015 and 2019, the Beck Archives curator taught forty-eight classes, with a total of nine hundred students, featuring primary sources from a variety of Beck collections. Departments that participated in the program included history, sociology, writing, emergent digital practices, languages and literatures, English, and art.

The model was adopted for cross-disciplinary library instruction and expanded in a cooperative effort across library departments, combining the skills and knowledge of special collections curators, reference instruction librarians, and faculty members who have professional affinity with 
the archives. This newly-established team melded visits to special collections archival collections with classroom instruction and class assignments, and created a program that combines the use of digital and physical primary resources to engage and inspire undergraduate students. Once faculty members who expressed interest were identified, the appropriate reference librarian and curator/archivist met with the professor to determine what primary source materials would fit the type of assignment the faculty member envisioned. For example, some professors assigned term papers, others shorter reflection papers, and still others used the encounter with primary sources to give students the opportunity to curate an exhibit. This program, titled Unmediated Archives: Creating an Immersive Experience for Undergraduate Students across the Disciplines, was the recipient of the 2018 Primary Source Award for Teaching from the Council of Research Libraries.

\section{The Beck Archives of Rocky Mountain Jewish History}

The Beck Archives was founded in 1976 by the late Peryle Hayutin Beck in memory of her husband, prominent Denver businessman Ira M. Beck. Archivists at the Beck Archives work in tandem with the Rocky Mountain Jewish Historical Society, part of the Center for Judaic Studies, also hosted by the University of Denver, to preserve the Jewish experience in the American West with an emphasis on Colorado. The Beck Archives houses over 300 collections and extends over 2,500 linear feet. ${ }^{1}$ Its collections have been the focus of a significant number of courses at DU, and it played a central role in the Unmediated Archives initiative.

The settlement of Denver coincided with the first Jewish presence in Colorado and as a result, Jews played a pivotal role in the region's economic, social, philanthropic, religious, and social development. Philanthropy, in particular, has been a major source of focus and recognition for Colorado Jews, since people first began flocking to the area in 1859, after gold was discovered near Pike's Peak. Thousands of men and women, including those of the Jewish faith, soon descended on the region in search of economic opportunity, adventure, and religious freedom (Uchill 1959; Abrams 2006).

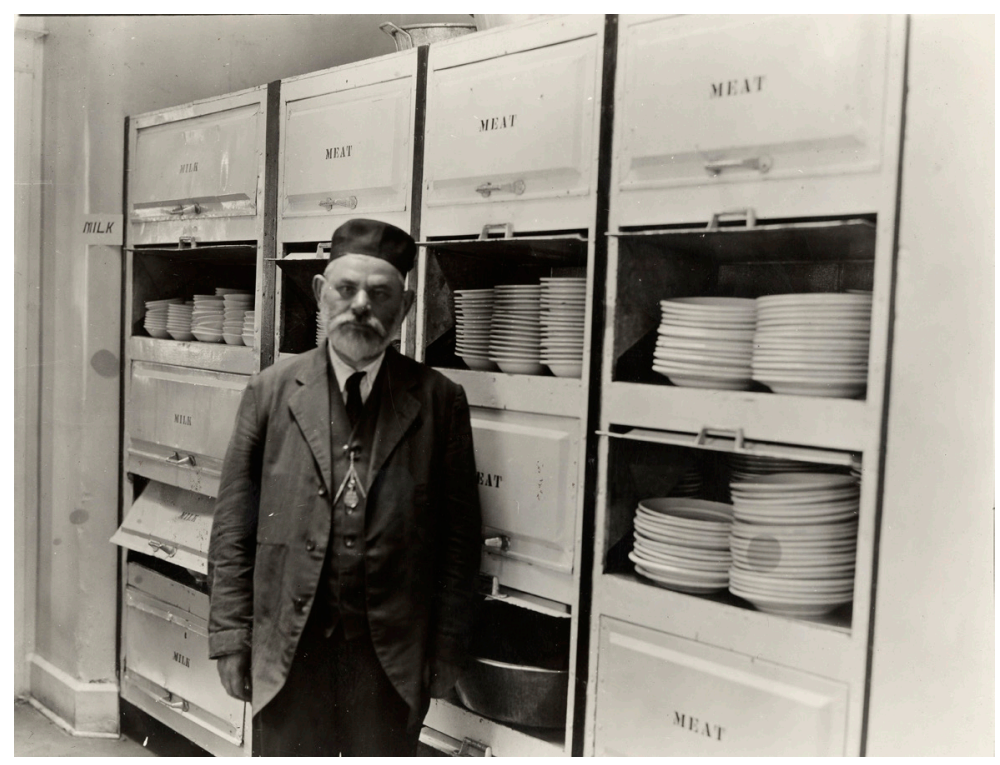

Figure 1. The mashgiach at the JCRS's kosher kitchen, c. 1930s. Beck Archives, Special Collections, Center for Judaic Studies and University Libraries, University of Denver

In the late nineteenth and early twentieth century, tuberculosis was the leading cause of death

${ }^{1}$ For more information about the collections, see https://duarchives.coalliance.org/collections. 
in Europe and the United States. In the absence of effective treatment, and because Colorado's dry, sunny climate and high altitude were considered healthful for consumptives, the state soon earned a reputation as the "World's Sanatorium." Until the National Jewish Hospital for Consumptives (NJH) opened its doors in 1899, there was no tuberculosis sanatorium available to treat the hundreds and then thousands of tuberculosis patients who descended on the state to "chase the cure" (Abrams 1990, 1, 3, 14). NJH was founded and funded by a group of largely affluent, acculturated and Americanized German reform Jews. As an expression of Jewish civic responsibility and Jewish philanthropic value of tzedakah, the hospital treated all patients free of charge and was formally non-sectarian, although until at least the 1930s the vast majority of patients were indigent Eastern European Jews.

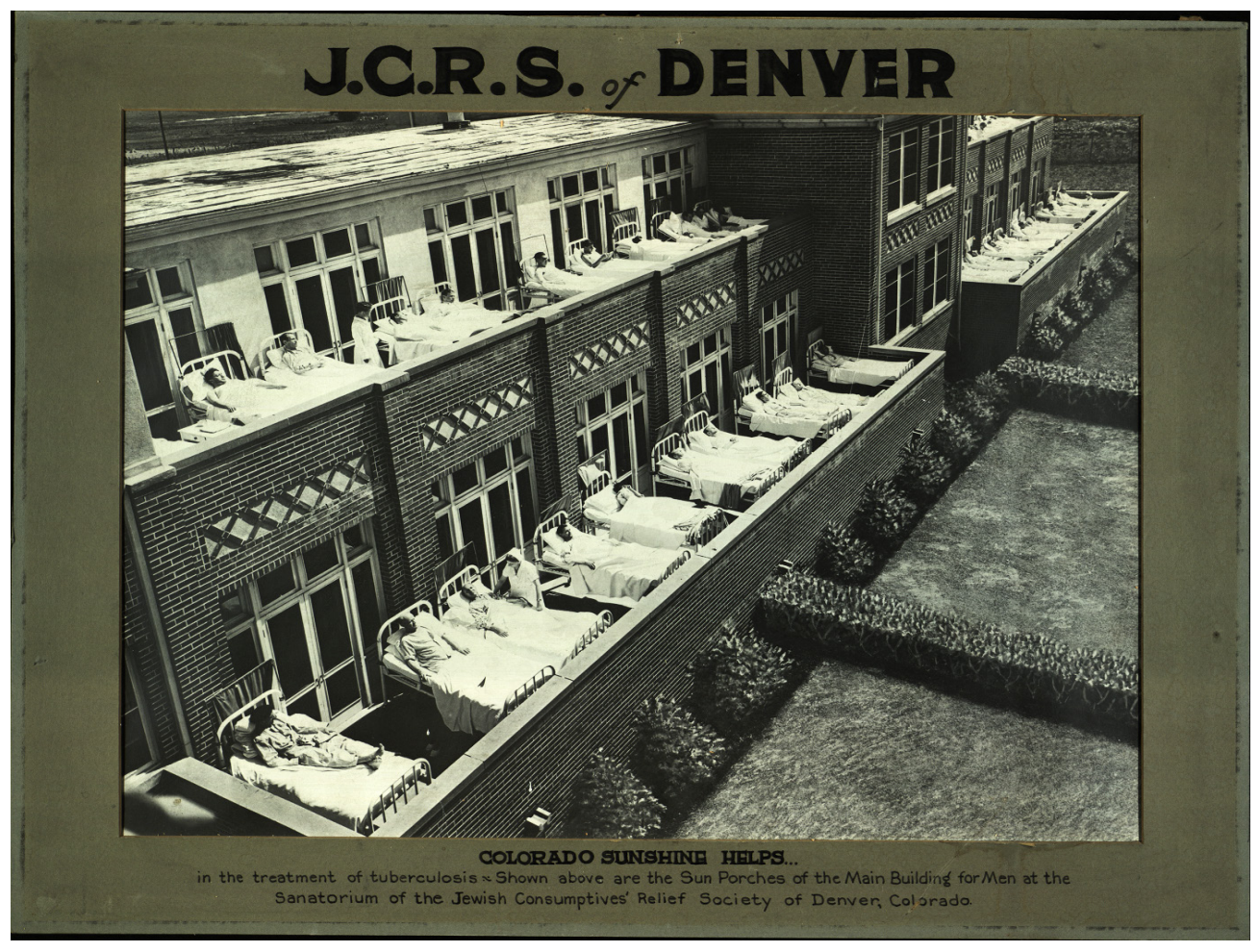

Figure 2. JCRS patients undergoing heliotherapy, c. 1930s. Beck Archives, Special Collections, Center for Judaic Studies and University Libraries, University of Denver

NJH performed admirable medical work but it had a number of strict rules. It only accepted patients with incipient tuberculosis, limited stays to six months, and required that patients arrive with $\$ 50$ to guarantee that they had sufficient funds to return to their place of origin rather than become a drain on the charity of the small local Jewish community. More challenging for many of the Russian Jewish patients was that NJH did not have a kosher kitchen and many felt that the German Jews operated in a condescending manner towards them (Figure 1). The proliferation of needy, ill patients and the cultural, social, and religious dissonance between the German and Eastern European Jews resulted in the founding of a second Jewish-based tuberculosis sanatorium in Denver, the Jewish Consumptives' Relief Society (JCRS), which opened in 1904. It was founded and funded by largely working-class Eastern European Jews. Like the NJH, it was formally non-sectarian, although the vast majority of patients were Russian Jews. More significantly, the 


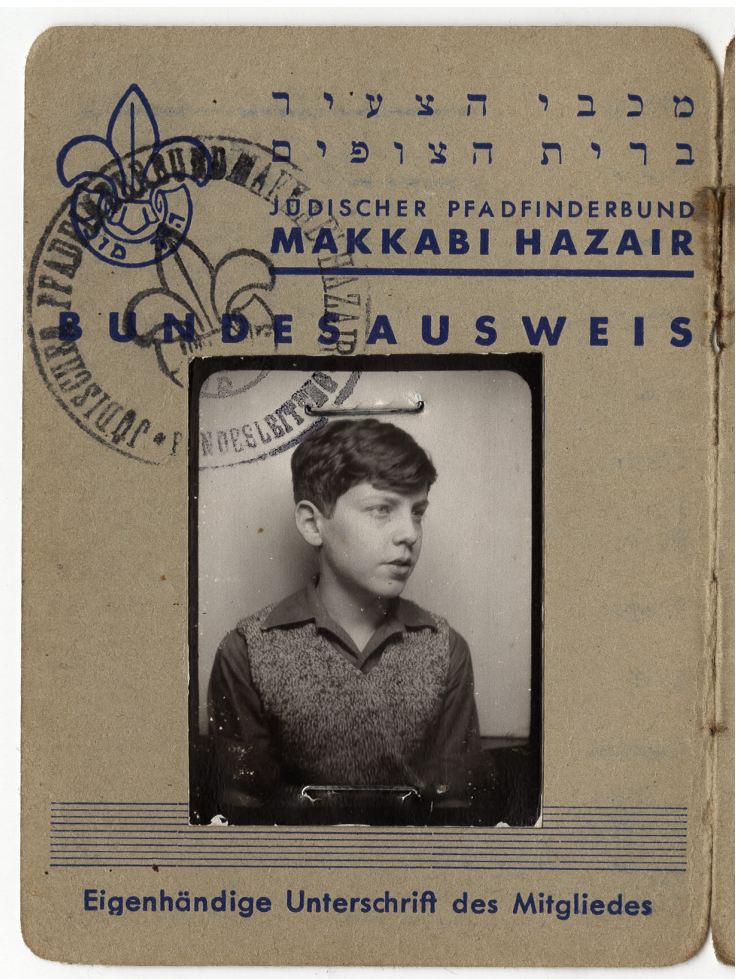

Figure 3. Henry Lowenstein's Boy Scout Card, Lowenstein Family Papers. Beck Archives, Special Collections, Center for Judaic Studies and University Libraries, University of Denver

JCRS accepted patients in all stages of the disease and included a kosher kitchen from the start. The JCRS also welcomed the use of the Yiddish language and provided a culturally Jewish environment. As one patient who experienced life in both sanatoriums put it, "NJH was a hospital, but the JCRS was a home" (Glass Interview, 1979).

The Beck Archives at the DU University Libraries holds the records of both the NJH and the JCRS, which feature evocative photographs and publications (Figure 2). The collections reflect American and Colorado Jewish history, as well as broader medical, philanthropic, social, and women's history. The JCRS Collection, in particular, includes robust patient records, which have been utilized frequently in class visits to the Beck Archives.

Another jewel in the Beck Archives collections is the Lowenstein Family Papers. Henry Lowenstein (1925-2014) was born and raised in Berlin. ${ }^{2}$ With the rise of Hitler and increasing danger for Jews in Nazi Germany, Henry's parents managed to send him to safety via the Kinderstransport to England, where he spent most of World War II (Figure 3). His parents remained behind in Germany, and although they faced terrible deprivation, they were not sent to concentration camps. Henry's parents and sister immigrated to the United States in 1946, and Henry followed from England the following year. The family was reunited in America in 1947. Henry's mother, Maria, who was an artist, brought with her many documents and family memorabilia, including two eviction notices issued by the Nazis and Henry's Jewish Boy Scout membership card, as well as some of the evocative drawings she had made in Berlin while living in daily fear for the lives of her husband and daughter.

After he immigrated to the United States, Henry first served in the air force, and then attended the Yale School of Drama beginning in 1953. He inherited his mother's artistic talent and became an acclaimed producer and set designer at Denver's Bonfils Theatre. Some of his most popular productions were "The Sound of Music" and "Harvey." Lowenstein also became an icon in the Denver theater scene. The Denver Annual Theater Award is named "The Henry" in his honor. The archival materials that constitute the Lowenstein Collection, including photographs, art works, correspondence, and official German documents, provide a glimpse into the lives of Jews under the Nazi regime and during the Holocaust, and into survivors' lives after the war. ${ }^{3}$

\footnotetext{
${ }^{2}$ For more information about Henry Lowenstein, see https:/history.denverlibrary.org/colorado-biographies/henry-lowenstein-1925-2014.

${ }^{3}$ See the DU Libraries Beck online exhibit at https://exhibits.library.du.edu/librariespresents/exhibits/show/ the-lowenstein-family.
} 


\section{Faculty Engagement with the Beck Archives}

Internal discussions among the library administration and university deans motivated the library to develop a program to bring diverse primary sources from the library collections to the attention of DU faculty. The Beck Archives, in particular, was long recognized as a "jewel in the crown" of the DU Libraries Special Collections and ways to make the Beck collections more visible and available to DU students became an increasing priority by 2013. About a decade ago, the library established a Library Liaison Advisory Group (LLAG), which included a faculty representative from each academic department on campus. Two or three times a year, LLAG members would be introduced to new library materials and projects at a library-organized luncheon. Special collections curators, including the Beck curator, often gave presentations highlighting some of the most engaging materials in their collections. Special collections curators also met individually with DU faculty in specific departments. Unsurprisingly, meetings with the history faculty were especially successful, and a number of history professors then asked the curators to assist them with scheduling class visits to the library to view particularly relevant collections.

Another path for encouraging professors was through the DU Center for Teaching and Learning (CTL). At one of the CTL workshops, the special collections curators and their reference librarian team colleagues organized a session in which professors who had successfully integrated special collections primary sources into their syllabi presented their individual experiences to encourage other faculty members to take advantage of archival resources. Lastly, when a number of faculty members who use primary source materials for their own research projects, individual curators discussed with them the possibility of developing class projects that would incorporate primary sources into their curricula.

Although history is a natural choice for primary source integration, professors who have incorporated Beck Archives materials also have included those who teach sociology, English, writing, languages and literatures, and media studies. It is encouraging to note that we never encountered any negative feedback from any faculty members who were approached to partner with the Beck Archives in using primary sources in their classes. Indeed, we were very gratified that every professor who was able to find a path to participate in the program was highly enthusiastic about the outcomes, which often included robust, engaging student term papers, presentations, and other projects. For example, a sociology professor who taught a class on the sociology of immigration in 2018 had her students create an exhibit, using facsimiles from materials from the Beck Archives and other special collections items. The exhibit was mounted in a prominent location in one of the classroom buildings and received acclaim by students and faculty members from a variety of disciplines. Moreover, every professor who participated in the primary source project came back to us repeatedly to recreate similar efforts for future classes.

\section{The Beck Archives and Student Experience at Denver University}

In each instance, the faculty member and the Beck Archives curator began by jointly providing an overview of how the class assignments related to immersion in the primary sources, and the faculty member then explained the student assignments in detail. The class syllabus was entirely designed by the faculty member, but with input from the archivist and reference librarian regard- 
ing the primary source assignment. The curator then explained what constitutes a primary source and provided historical background and context on the primary sources that were being shared. In addition, reference librarians assigned to a specific class held a separate session with students to demonstrate how to access digital primary resources available through the DU library. The students were encouraged to contact the Beck Archives curator for specific follow-up questions about collection content that related to their assignments.

An initial in-depth discussion among the faculty member, archivist, and reference librarian was held to assess the faculty expectation for the use of primary sources and to determine how the collection could best be used to fulfill a student assignment or project. In many cases, particularly when students were required to produce full-length term papers, an exercise was introduced to provide students with basic guidance in examining and analyzing primary sources (see the Appendix for the Fall 2016 exercise form). At the end of the introductory session, brief questionnaires were distributed to students to assess their reactions.

Written feedback from professors was used to gauge the success of the student experience. Nearly all of the forty-eight professors we worked with sent us at least brief comments about their use of Beck materials in their classes, and they were all positive. In addition, faculty members were asked to report on the use of Beck primary sources in student assignments and student success in fulfilling assignment expectations. They wrote, "Just thought you should know that you really did make a difference for our students - helped them with sources and interpretations, set an example with your own scholarship, and energized their interest in the subject... [we] sincerely appreciate it, every bit as much as our students did."

\section{Undergraduate Student Work with the Beck Archives}

It is interesting to note that to date, none of the classes which have incorporated primary source projects related to collections in the Beck Archives were from the DU Center for Judaic Studies. Instead, departments of history, sociology, and languages and literatures predominated. The materials that were selected from the Beck Archives were clearly appreciated by all the students, Jewish and non-Jewish alike. Indeed, the students appeared to appreciate the materials they examined as reflective of the diverse American and immigrant experience. In the case of the Lowenstein Collection, in particular, many students indicated that they gained better insight into the horrors of the Holocaust for Jewish victims and the terrible human costs brought on by anti-Semitism, intolerance, and prejudice. Several students commented that although they were broadly familiar with the decimation of the Jewish population in Germany and Eastern Europe as a result of the Nazi regime during WWII, examining the photos and documents in the Lowenstein Collection made the stories more vivid and personal.

Some fifty undergraduate courses have integrated primary sources from the Beck Archives into their curricula. A class in sociology research methods consulted tuberculosis patient records from Denver's JCRS sanatorium, modeling research questions about individuals' lives as well as broader social conditions at the beginning of the twentieth century. To avoid privacy issues, pa- 
tient records created before 1930 were selected for this and other class assignments. The students created a series of reflection papers that aided them in learning how to collect data and conduct meaningful interviews. Honors classes in the history of medicine used the JCRS materials as the basis for term papers, and students gained deep insight into how tuberculosis affected patients and their families and the nature of early tuberculosis treatment in America before the introduction of antibiotics to help bring the disease under control.

Students in a variety of classes from history to languages and literatures, and writing have utilized materials from the Lowenstein Collection to gain a better insight into the horrors of the Holocaust. An English professor, who teaches Jewish immigrant literature, made objects in the Beck Archives the centerpiece of student term papers. Students chose artifacts that resonated with them to create their own immigrant story narrative. One student chose a pair of brass Shabbat candlesticks as her focus. A Russian Jewish immigrant to Denver in the early years of the twentieth century had brought only her clothing and the candlesticks along with her on her journey. The Shabbat candlesticks demonstrated to the student the vital role Jewish traditions had played in the lives of many early immigrants and brought a personal voice and perspective to the broader phenomenon of immigration.

\section{CONCLUSION}

These examples from the University of Denver Libraries initiative to integrate archival primary sources into the undergraduate curricula demonstrate the teaching value that special collections present. The Beck Archives of Rocky Mountain Jewish History played and continues to play a pivotal role in the ongoing project. The success of the undertaking reinforces our working assumption that materials in archival collections can become a valuable part of teaching and learning toolkits. Integrating primary sources into undergraduate class curricula also has the potential to develop a broader appreciation of the unique resources held by libraries and archival institutions and generate more robust financial support for our services, both within the university and across the wider community.

\section{SOURCES}

Abrams, Jeanne. 1990. Blazing the Tuberculosis Trail: The Religo-Ethnic Role of Four Sanatoria in Early Denver. Denver: Colorado Historical Society. . 2006. Jewish Women Pioneering the Frontier Trail: A History in the American West. New York: New York University Press.

. 2009. Dr. Charles David Spivak: A Jewish Immigrant and the American Tuberculosis Movement. Boulder, CO: University of Colorado Press.

Garcia, Patricia. 2017. "Accessing Archives: Teaching with Primary Sources in K-12 Classrooms." The American Archivist 80 (1): 189-212 
Glass, Ben and Bessie. Sound Recording with Ben and Bessie Glass, August 16, 1979, Denver, Colorado by Alby Segall; B098.08.0009.00001, Oral History Collection, Beck Archives of Rocky Mountain Jewish History, University of Denver.

Norman, Amanda, and Amie Oliver. 2014. "Cultivating Class Projects in the Archives." Archival Outlook (May/June 2014): 10-11, 25.

Uchill, Ida. 1959. Pioneers, Peddlers, and Tsadikim. Denver: Sage Press.

Yaco, Sonia, Caroline Brown, and Lee Konrad. 2016. "Linking Special Collections to Classrooms: A Curriculum-to Collection Crosswalk." The American Archivist 79 (2): 417-477. 


\section{Appendix: Lowenstein Primary Source Exercise}

\section{Beck Archives, Special Collections, University of Denver Libraries, Fall 2016}

1. What types of items are these? Describe each item in a few sentences, including the main idea/concept of each, when it was produced, what person/group of people produced it, and why/for what purpose you think it was produced.

2. What can you tell about the people/groups that created the items based on a review of the items (and any additional contextual information provided by the archivist)? Are the creators of the items also the subjects of the items?

3. What are the uses of these items for research? What information can we derive from them? What do they let us confirm? Can you determine when the item was produced? What clues do the documents provide that help you to determine a reasonable date range?

4. What are the limits of these items for research? What do they not contain, or what other questions are you left with?

5. What information do the documents reveal about the Lowenstein Family and how the Holocaust affected individual victims in Europe and/or the immigrant experience?

6. What kinds of research questions could these items be used to answer or what type or research questions do they raise for you? 